\title{
Use of Profiler Moorings in the Ocean Observatories Initiative
}

\author{
Matthew Palanza* and John Lund \\ Woods Hole Oceanographic Institution, USA
}

Submission: July 26, 2019; Published: August 12, 2019

Corresponding author: Matthew Palanza, Woods Hole Oceanographic Institution, 266 Woods Hole Road, Woods Hole, Ma 02543, USA

Abstract

This Mini Review is intended to describe the history, design, and summarize the performance of one class of mooring used by the Ocean Observatories Initiative.

Keywords: Ocean Observatories Initiative; Observatory; Mooring; Buoy

Abbreviations: OOI: Ocean Observatories Initiative; NSF: National Science Foundation; WHOI: Woods Hole Oceanographic Institution; WFP: Wire Following Profilers; MMP: McLane Moored Profiler; ADCP: Acoustic Doppler Current Profiler; GPS: Global Positioning System

\section{Introduction}

The Ocean Observatories Initiative (OOI) [1], supported by the National Science Foundation, is directed to operate and maintain arrays of moored and mobile assets in four locations around the globe. These locations include two coastal arrays off the east and west coasts of the United States and two global arrays in the Irminger Sea, and North Pacific. These arrays are currently functional, supplying oceanographic data to the scientific community in near real time. There are several types of moorings continuously deployed in these locations. The Coastal Profiler Moorings [2] are instrumented and designed to resolve compelling scientific “Essential Ocean Variables” through sustained measurements of ocean processes and properties. The OOI represents the result of more than two decades of scientific planning, leading to a deployed operating infrastructure based on science requirements derived from science themes. The OOI has an expected operation of 25 years or more, and data are freely available to users via the Internet. Wire Following Profilers have been in continuous operation at the Pioneer Array [3] since April of 2014 (Figure 1).

\section{Discussion}

The 00I Wire Following Profiler Mooring is a combination of prior art and a commercially available product. The "Whale Detection Mooring" [4] designed and operated by Woods Hole Oceanographic Institution (WHOI) was adapted as a near realtime platform for a McLane Moored Profiler [5] (MMP). Profiler Moorings consist of a surface buoy containing batteries, singleboard computer, and telemetry modules (GPS, Iridium ISU,
Iridium SBD, Wi-Fi, Free Wave Radio, Radar Target Enhancer, and a XEOS KILO beacon). The mooring riser includes a 50 -foot stretch hose that serves as a compliant member to de-couple surface motion from the remainder of the mooring. The stretch hose includes electrical conductors to transmit data from the instruments. A 64" syntactic foam sphere provides tension for the inductive 5/16 jacketed wire rope that the Wire Following Profiler (WFP) climbs up and down. The wire rope, along with the seawater ground, provides the inductive pathway to transmit data from both the WFP and Teledyne RDI Acoustic Doppler Current Profiler (ADCP). There are two acoustic releases above the anchor which allow the riser portion to be detached from the anchor for recovery. The second acoustic release allows a line pack, attached to the anchor, to float to the surface so that the 6000 lbs. anchor can be recovered separately using a heavy lift winch.

\section{WFP Sensor Package}

McLane Moored Profilers include:

i. $\quad$ CTD - Sea Bird 52MP pumped CTD with attached

ii. Sea Bird 43F Dissolved Oxygen sensor

iii. Fluorometer - WetLabs ECOBBFL2

iv. Acoustic Current Meter - Nortek Aquadopp2DVS

v. PAR (Photosynthetic Available Radiation) sensor - Bio spherical Instruments QSP-2200 


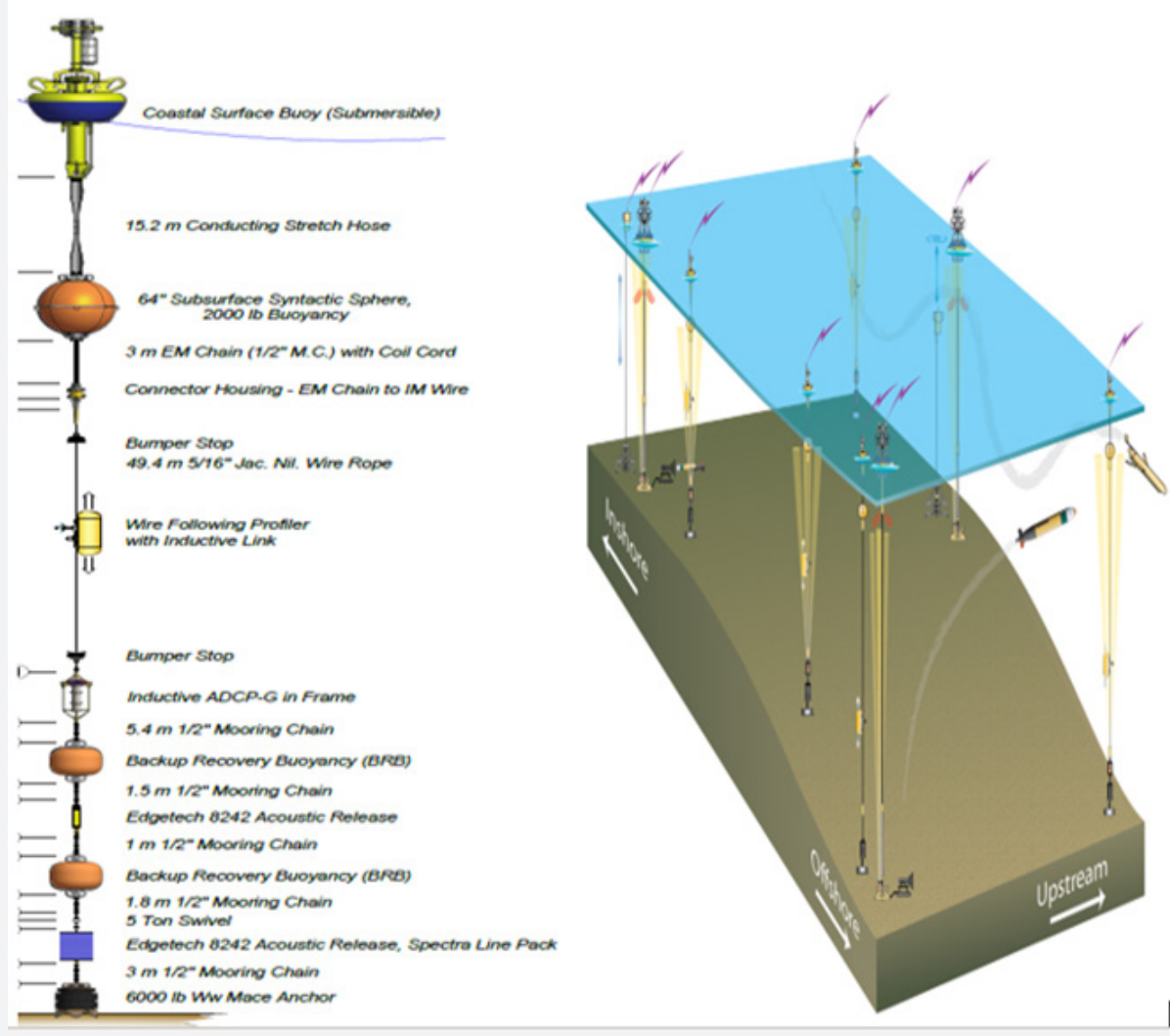

Figure 1: Mooring Schematic and Pioneer Array Isometric Diagram.

Profilers Moorings are serviced approximately every 6 months. Deployed moorings are recovered, and newly refurbished moorings are redeployed in nominally the same location. During the refurbishment period all batteries are replaced, instruments returned to vendors for recalibration. Telemetry and riser components, including the stretch hose, are inspected and serviced. Inductive wire rope and chain sections are replaced. Anchors, buoyancy spheres and buoy flotation foam are cleaned and painted. Buoys and instruments are reintegrated and burned-in for several weeks prior to redeployment.

\section{Conclusion}

Table 1: Profiler Mooring Operational Statistics

\begin{tabular}{|c|c|c|c|c|}
\hline $\begin{array}{c}\text { Mooring Reference } \\
\text { Designator }\end{array}$ & Dates & $\begin{array}{c}\text { Number of Deployments } \\
\text { Completed }\end{array}$ & $\begin{array}{c}\text { Number of Profiles } \\
\text { Completed }\end{array}$ & $\begin{array}{c}\text { Vertical Distance } \\
\text { Profiled (Meters) }\end{array}$ \\
\hline CP02PMCI & $4 / 2014-4 / 2019$ & 11 & 22,625 & $1,629,000$ \\
\hline CP02PMCO & $4 / 2014-4 / 2019$ & 11 & 23,025 & $2,164,350$ \\
\hline CP02PMUI & $11 / 2013-4 / 2019$ & 12 & 21,972 & 900,852 \\
\hline CP02PMUO & $4 / 2014-4 / 2019$ & 12 & 11,611 & $3,448,467$ \\
\hline CP04OSPM & $4 / 2014-4 / 2019$ & 10 & 11,949 & $3,447,287$ \\
\hline CP01CNPM & $11 / 2017-4 / 2019$ & 2 & 4,215 & 261,330 \\
\hline CP03ISPM & $11 / 2017-4 / 2019$ & 2 & 5,085 & 167,805 \\
\hline Total & & 60 & 100,482 & $12,019,091$ \\
\hline
\end{tabular}

The continuous operation of these systems since 2014 data for performance analysis. This has allowed the operators has generated a statistically significant amount of engineering to provide direct feedback to the vendor. The WFP has been

\section{MMP Missions}

Profilers that operate in depths shallower than 200 meters are programmed to make full profiles every 90 minutes. The collected profile data is inductively transferred to the surface buoy every other dive. When the surface buoy is woken up by the profiler it initiates an Iridium data call to the OOI servers. Profilers (CP02PMUO and PC040SPM) operating in water deeper that 200 meters perform a half profile to/from 200 meters between each full profile. These Profilers are programmed to profile every 180 minutes. Similarly, they telemeter data every other dive. 
improved over time with this information and has led to an improved product for OOI and all users of this technology. Table one below is summary of operational statistics. Each platform deployed for the Ocean Observatories Initiative has a specific Reference Designator that indicates the type of system and its location. Column 1 are the seven deployed at the Pioneer Array. Column two are the deployement dates used to generate the data in columns three, four and five. The WFP has proven to be a robust, and effective platform. Since 2014, there have been 60 separate deployments, with over 100,000 profiles completed for a total of over 12 million meters of vertical travel (Table 1).

\section{Acknowledgement}

This work was supported by the National Science Foundation through the Cooperative Agreement OCE-1743430 to the Woods Hole Oceanographic Institution

\section{References}

1. Ocean Observatories Initiative (2019) The Ocean Observatories Initiative Online.

2. Ocean Observatories Initiative (2019) Central Profiler Mooring (CP01CNPM).

3. Ocean Observatories Initiative (2019) Pioneer-Array-Handout_2018-03-23_ver_5-00.

4. Woods Hole Oceanographic Institution (2009) Buoys Help Avert Whale-Ship Collisions.

5. McLane Research Laboratories (2019) McLane Moored Profiler.

\section{Your next submission with Juniper Publishers} will reach you the below assets

- Quality Editorial service

- Swift Peer Review

- Reprints availability

- E-prints Service

- Manuscript Podcast for convenient understanding

- Global attainment for your research

- Manuscript accessibility in different formats

( Pdf, E-pub, Full Text, Audio)

- Unceasing customer service

Track the below URL for one-step submission

https://juniperpublishers.com/online-submission.php 